\title{
Review
}

\section{Developing countries: health round-trip}

\author{
Lourdes Moreno Cea1 ${ }^{1}$, Virginia Fernández Espinilla ${ }^{1}$, Gema Ruiz López del Prado ${ }^{1}$, Cristina Hernán \\ García ${ }^{1}$, Javier Cepeda Casado ${ }^{2}$, M $^{a}$ José Polo Polo ${ }^{1}$, Antonio Delgado Márquez ${ }^{1}$, Irene Andrés García ${ }^{1}$ \\ ${ }^{1}$ Servicio de Medicina Preventiva y Salud Pública, Hospital Clínico Universitario, Valladolid, Spain \\ ${ }^{2}$ Servicio de Psiquiatría, Hospital Clínico Universitario, Valladolid, Spain
}

\begin{abstract}
International travel can pose various risks to health, depending both on the health needs of the traveller and on the type of travel to be undertaken. Travellers intending to visit a destination in a developing country should consult a travel medicine clinic or medical practitioner before the journey. General precautions can greatly reduce the risk of exposure to infectious agents. Vaccination is a highly effective method of preventing certain infectious diseases.

The aim of this study is to know the risks involved and the best way to prevent them.
\end{abstract}

Key words: international travel; developing countries; travel health risks; vaccines; infectious diseases; preventive measures.

J Infect Dev Ctries 2015; 9(1):020-028. doi:10.3855/jidc.4645

(Received 02 January 2014 - Accepted 12 January 2014)

Copyright (C) 2015 Moreno Cea et al. This is an open-access article distributed under the Creative Commons Attribution License, which permits unrestricted use, distribution, and reproduction in any medium, provided the original work is properly cited.

\section{Travel-related risks}

According to statistics from the World Tourism Organization, international tourist arrivals worldwide in 2010 for business, leisure and other purposes amounted to 940 million.

International travel can pose various risks to health, depending both on the health needs of the traveller and on the type of travel to be undertaken. Travellers may encounter sudden and significant changes in altitude, humidity, temperature and exposure to a variety of infectious diseases, which can result in illness. In addition, serious health risks may arise in areas where accommodation is of poor quality, hygiene and sanitation are inadequate, medical services are not well developed and clean water is unavailable.

All individuals planning travel should seek advice on the potential hazards of their chosen destinations and understand how best to protect their health and minimize the risk of acquiring disease. Forward planning, appropriate preventive measures and careful precautions can protect their health and minimize the risks of accidents and acquiring disease [1].

\section{Medical consultation before travel}

Travellers intending to visit a destination in a developing country should consult a travel medicine clinic or medical practitioner before the journey (http://www.ecdc.europa.eu). This consultation should take place at least 4-8 weeks before the journey, preferably earlier if long-term travel or overseas work is envisaged. The consultation will include information about the most important health risks (including traffic accidents), determine the need for any vaccinations and/or antimalarial medication and identify any other medical items that the traveller may require [2]. A basic medical kit will be prescribed, supplemented as appropriate, to meet individual needs. All travellers should be strongly advised to seek comprehensive travel insurance.

Medical advisors base their recommendations, including those for vaccinations and other medication, on a risk assessment for the individual traveller, which takes into account the likelihood of acquiring a disease and how serious this might be for the person concerned. Key elements of this risk assessment are: the pre-travel health status of the traveller, destination(s), duration and purpose of travel, the mode of transport, standards of accommodation and food hygiene, and risk behaviour while travelling $[3,4]$.

\section{Medical kit and toilet items}

A medical kit should be carried to all destinations where there may be significant health risks, particularly those in developing countries and/or 
where the local availability of specific medications is uncertain. This kit will include basic medicines to treat common ailments, first-aid articles, and any other special medical items, such as syringes and needles (to minimize exposure to blood-borne viruses), that may be required and can in some cases be used by the individual traveller. (Table 1)

Certain categories of prescription medicine or special medical items should be carried together with a medical attestation on letterhead, signed by a physician, certifying that the traveller requires the medication or the items for a specific medical condition. Some countries require that this attestation be signed not only by a physician but also by the national health administration.

Health risks associated with travel are greater for certain groups of travellers, including infants and young children, pregnant women, the elderly, the disabled, the immune-compromised and those who have pre-existing health problems.

\section{Insurance for travellers}

Travellers are strongly advised to travel with comprehensive travel insurance as a matter of routine and to declare any underlying health conditions to their travel insurer.

This health insurance should include coverage for changes to the itinerary, emergency evacuation for health reasons, hospitalization, medical care in case of illness or accident and repatriation of the body in case of death. Travellers should discuss with the parties concerned any issues or claims as they happen and not upon return from the trip [5].

\section{Diseases and vaccines}

Depending on the travel destination, travellers may be exposed to a number of infectious diseases; exposure depends on the presence of infectious agents in the area to be visited. The risk of becoming infected will vary according to the purpose of the trip and the itinerary within the area, the standards of accommodation, hygiene and sanitation, as well as the behaviour of the traveller. In some instances, disease can be prevented by vaccination, but there are some infectious diseases, including some of the most important and most dangerous, for which no vaccines currently exist.

General precautions can greatly reduce the risk of exposure to infectious agents and should always be taken for visits to any destination where there is a significant risk of exposure, regardless of whether any vaccinations or medication have been administered [6].).

The modes of transmission for different infectious diseases and the corresponding general precautions are outlined in the following paragraphs.

- Food-borne and water-borne diseases

- Vector-borne diseases

- Zoonoses (diseases transmitted by animals)

- Sexually transmitted diseases

- Blood-borne diseases

- Airborne diseases

- Diseases transmitted via soil

The most common infectious illness, affecting travellers is travellers' diarrhoea. This can be caused by many different food-borne and water-borne infectious agents, for which treatment and precautions are essentially the same.

Vaccination is a highly effective method of preventing certain infectious diseases. Vaccines are generally very safe, and serious adverse reactions are uncommon. Routine immunization programmes protect most of the world's children from a number of infectious diseases that previously claimed millions of lives each year. For travellers, vaccination offers the possibility of avoiding a number of infectious diseases that may be encountered abroad. However, satisfactory vaccines have not yet been developed against several of the most life-threatening infections, including tuberculosis, malaria and HIV/AIDS.

\section{Choice of vaccines for travel}

Vaccines for travellers include: (1) basic vaccines used in most national routine programmes, particularly but not only in children; (2) vaccines that are recommended before travelling to particular countries or areas; (3) vaccines required by the International Health Regulations. (Table 2)

Several of the vaccines that are routinely administered in childhood require one or more booster doses to maintain an effective level of immunity. Adults often neglect the need for booster vaccinations, particularly if the risk of infection is low. Some adults, particularly the elderly, may never have been vaccinated. It is important to realise that diseases such as diphtheria and poliomyelitis, which are eliminated in most industrialized countries, may be present in countries frequently visited by travellers. 
Table 1. Contens of basic medical kit.

\begin{tabular}{|c|c|}
\hline First-aid items & $\begin{array}{l}\text { Basic Medical Kit } \\
\text { Additional items according to destination and individual needs }\end{array}$ \\
\hline Adhesive tape & Medication for pre-existing medical conditions. \\
\hline $\begin{array}{l}\text { Antiseptic wound cleanser or } \\
\text { alkaline soap }\end{array}$ & $\begin{array}{l}\text { Antidiarrhoeal medication (to include an antisecretory agent, an antimotility drug, oral rehydration salts, } \\
\text { with appropriate written instructions regarding their use) }\end{array}$ \\
\hline Bandages & $\begin{array}{l}\text { Antibiotics targeting the most frequent infections in travellers (e.g. travellers' diarrhoea, and infections } \\
\text { of skin and soft-tissue, respiratory tract and urinary tract) }\end{array}$ \\
\hline Scissors & Antibacterial ointment \\
\hline Insect repellent & Mosquito net and insecticide to treat fabrics (clothes, nets, curtains) \\
\hline Insect bite treatment & Adequate supplies of condoms and oral contraceptives \\
\hline Antihistamine tablets & Medication for pre-existing medical conditions \\
\hline Nasal decongestant & Sterile syringes and needles \\
\hline Oral rehydration salts & Water disinfectant \\
\hline \multicolumn{2}{|l|}{ Clinical thermometer } \\
\hline \multicolumn{2}{|l|}{ Sunscreen } \\
\hline \multicolumn{2}{|l|}{ Earplugs } \\
\hline \multicolumn{2}{|l|}{ Tweezers } \\
\hline $\begin{array}{l}\text { Adhesive strips to close small } \\
\text { wounds. }\end{array}$ & \\
\hline
\end{tabular}

Table 2. Vaccines for travellers.

\begin{tabular}{|c|c|}
\hline Category & Vaccines \\
\hline \multirow{12}{*}{ Routine vaccination } & Diphtheria \\
\hline & Hepatitis B \\
\hline & Haemophilus influenzae type b \\
\hline & Seasonal influenza ${ }^{\mathrm{b}}$ \\
\hline & Measles \\
\hline & Mumps \\
\hline & Rubella \\
\hline & Pneumococcal disease \\
\hline & Poliomyelitis (Polio) \\
\hline & Rotavirus $^{\text {a }}$ \\
\hline & Tuberculosis $(\mathrm{TB})^{\mathrm{c}}$ \\
\hline & Tetanus \\
\hline \multirow{6}{*}{ Selective use for travellers } & Japanese encephalitis ${ }^{\mathrm{e}}$ \\
\hline & Meningococcal disease ${ }^{\mathrm{e}}$ \\
\hline & Rabies \\
\hline & Tick-borne encephalitis ${ }^{\mathrm{e}}$ \\
\hline & Typhoid fever \\
\hline & Yellow fever ${ }^{\mathrm{e}}$ \\
\hline \multirow{2}{*}{ Required vaccination } & Yellow fever \\
\hline & Meningococcal disease and polio (required by Saudi Arabia for pilgrims,) \\
\hline
\end{tabular}


Table 3. Diseases and vaccines.

\begin{tabular}{|c|c|c|c|}
\hline Diseases & Hepatitis B & Tetanus & Poliomyelitis \\
\hline Cause & $\begin{array}{l}\begin{array}{l}\text { Hepatitis } \mathrm{B} \text { virus } \\
\text { family) }\end{array} \\
\end{array}$ & $\begin{array}{l}\text { The bacterium Clostridium tetani }(C \text {. } \\
\text { tetani) }\end{array}$ & $\begin{array}{l}\text { Poliovirus types } 1,2 \text { and } 3 \text { (three } \\
\text { closely related enteroviruses). }\end{array}$ \\
\hline Transmission & $\begin{array}{l}\text { Infection is transmitted from person to } \\
\text { person by contact with infected body } \\
\text { fluids (Sexual contact, transfusion of } \\
\text { contaminated blood or blood products). } \\
\text { Perinatal transmission. There is no } \\
\text { insect vector or animal reservoir. }\end{array}$ & $\begin{array}{l}\text { Tetanus is acquired through exposure } \\
\text { to the spores of } C \text {. tetani which are } \\
\text { present in soil worldwide. The disease } \\
\text { is not communicable. }\end{array}$ & $\begin{array}{l}\text { Predominantly by the faecal-oral } \\
\text { route. }\end{array}$ \\
\hline $\begin{array}{l}\text { Geographical } \\
\text { distribution }\end{array}$ & $\begin{array}{l}\text { HBV is found worldwide, but with } \\
\text { differing levels of endemicity. }\end{array}$ & $\begin{array}{l}\text { Wounds can become infected with the } \\
\text { spores of C. tetani anywhere in the } \\
\text { world. }\end{array}$ & $\begin{array}{l}\text { Endemic in Afghanistan, Nigeria and } \\
\text { Pakistan - and has reestablished } \\
\text { transmission in three countries which } \\
\text { were previously polio-free (Angola, } \\
\text { Chad and the Democratic Republic of } \\
\text { the Congo). Several other countries } \\
\text { had ongoing outbreaks due to } \\
\text { importations of poliovirus. }\end{array}$ \\
\hline
\end{tabular}

\begin{tabular}{|c|c|c|c|}
\hline $\begin{array}{l}\text { Risk } \\
\text { travellers }\end{array}$ & $\begin{array}{l}\text { for Principal risky activities include } \\
\text { unprotected sexual intercourse with an } \\
\text { infected person; health care } \\
\text { interventions (medical, dental, } \\
\text { laboratory or other) that entail direct } \\
\text { exposure to human blood or body } \\
\text { fluids; receipt of a transfusion of blood } \\
\text { that has not been tested for HBV; and } \\
\text { exposure to needles (e.g. acupuncture, } \\
\text { piercing, tattooing or injecting drug } \\
\text { use) that have not been appropriately } \\
\text { sterilized. In addition, transmission } \\
\text { from HBV-positive to HBV- } \\
\text { susceptible individuals may occur } \\
\text { through direct contact between open } \\
\text { skin lesions following a penetrating } \\
\text { bite or scratch. }\end{array}$ & $\begin{array}{l}\text { Every traveller should be fully } \\
\text { vaccinated against tetanus. Almost any } \\
\text { form of injury, from a simple } \\
\text { laceration to a motor-vehicle accident, } \\
\text { can expose the individual to the spores. }\end{array}$ & \\
\hline $\begin{array}{l}\text { General } \\
\text { precautions }\end{array}$ & $\begin{array}{l}\text { Protected sexual intercourse. Avoid } \\
\text { exposure to human blood or body } \\
\text { fluids. }\end{array}$ & & \\
\hline Vaccines & $\begin{array}{l}\text { Hepatitis B vaccine should be } \\
\text { considered for all non-immune } \\
\text { individuals travelling to countries or } \\
\text { areas with moderate to high risk of } \\
\text { infection. It can be administered to } \\
\text { infants from birth. }\end{array}$ & $\begin{array}{l}\text { All travellers should be up to date with } \\
\text { the vaccine before departure. The type } \\
\text { of tetanus prophylaxis that is required } \\
\text { following injury depends on the nature } \\
\text { of the lesion and the history of } \\
\text { previous immunizations. However, no } \\
\text { booster is needed if the last dose of the } \\
\text { primary series, or of subsequent } \\
\text { booster injections was given less than } \\
5 \text { years ago for dirty wounds or less } \\
\text { than } 10 \text { years ago for clean wounds. }\end{array}$ & $\begin{array}{l}\text { All travellers to and from poliovirus- } \\
\text { infected areas should be adequately } \\
\text { vaccinated. Required by Saudi Arabia } \\
\text { for pilgrims }\end{array}$ \\
\hline
\end{tabular}


Table 4. Diseases and vaccines.

\begin{tabular}{|c|c|c|c|}
\hline Diseases & Cholera & Hepatitis A & Typhoid fever \\
\hline Cause & $\begin{array}{l}\text { Vibrio cholerae (serogroups } \mathrm{O} 1 \text { and } \\
\text { O139). }\end{array}$ & $\begin{array}{l}\text { Hepatitis A virus (Picornaviridae } \\
\text { family). }\end{array}$ & $\begin{array}{l}\text { The typhoid bacillus Salmonella } \\
\text { typhi, which infects humans only. }\end{array}$ \\
\hline Transmission & $\begin{array}{l}\text { Infection occurs through ingestion of } \\
\text { food or water contaminated directly } \\
\text { or indirectly by faeces or vomitus of } \\
\text { infected individuals. Cholera affects } \\
\text { only humans; there is no insect } \\
\text { vector or animal reservoir host. }\end{array}$ & $\begin{array}{l}\text { The virus is acquired through close } \\
\text { contact with infected individuals or } \\
\text { through faecally contaminated food } \\
\text { or drinking-water. There is no insect } \\
\text { vector or animal reservoir. }\end{array}$ & $\begin{array}{l}\text { The typhoid bacillus is transmitted } \\
\text { by consumption of contaminated } \\
\text { food or water. }\end{array}$ \\
\hline $\begin{array}{l}\text { General } \\
\text { precautions }\end{array}$ & $\begin{array}{l}\text { As for other diarrheal diseases, } \\
\text { precautions should be taken to avoid } \\
\text { consumption of potentially } \\
\text { contaminated food, drinks and water. } \\
\text { Oral rehydration salts (ORS) should } \\
\text { be carried to combat dehydration and } \\
\text { electrolyte depletion in case of } \\
\text { severe diarrhea. }\end{array}$ & $\begin{array}{l}\text { Avoid or boil potentially } \\
\text { contaminated food and water. Short- } \\
\text { term protection through injection of } \\
\text { human immune globulin is gradually } \\
\text { being replaced worldwide by } \\
\text { hepatitis A vaccination. }\end{array}$ & $\begin{array}{l}\text { For general precautions against } \\
\text { exposure to foodborne and } \\
\text { waterborne infections }\end{array}$ \\
\hline
\end{tabular}


Table 5. Diseases and vaccines.

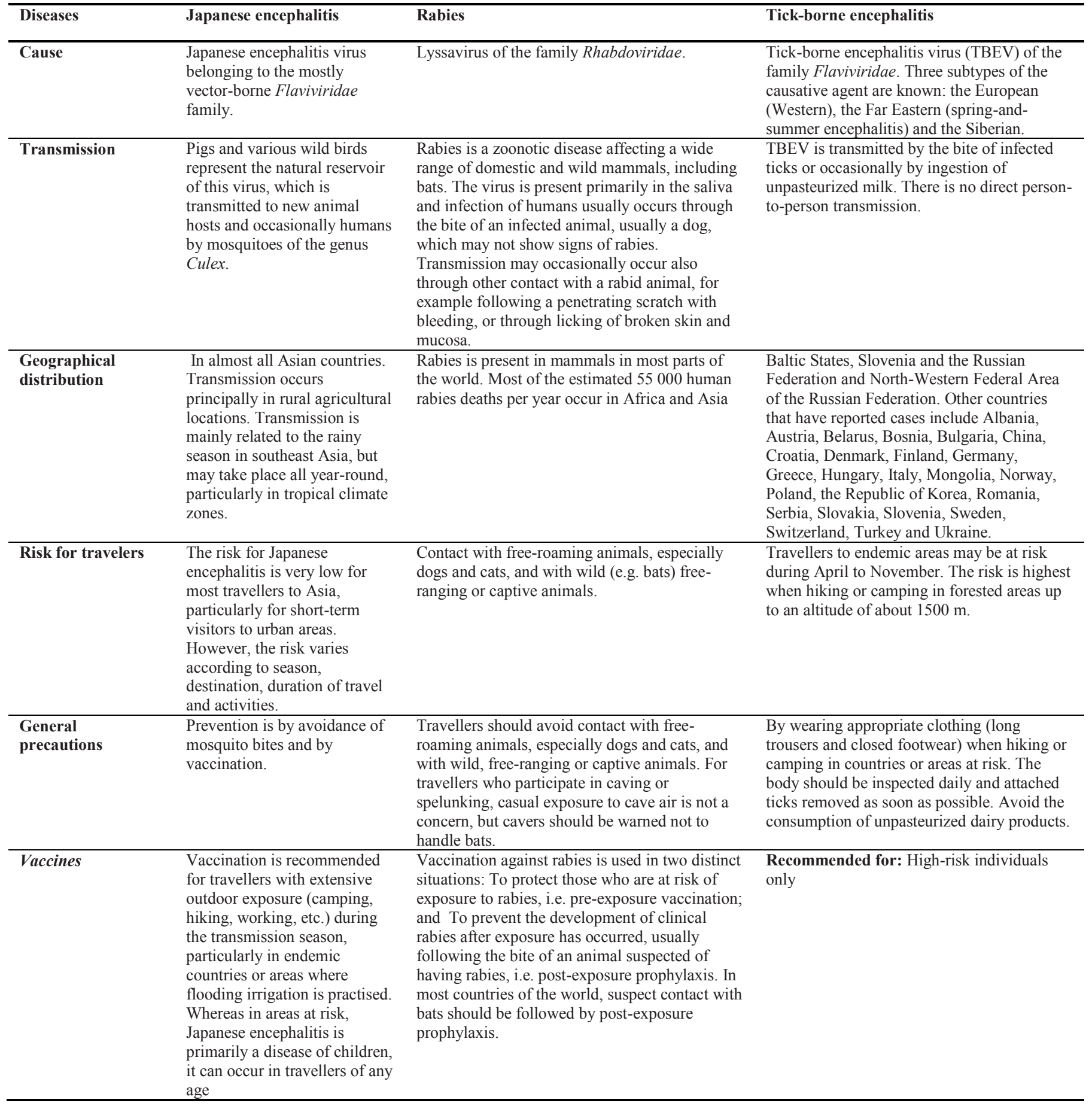


Table 6. Diseases and vaccines.

\begin{tabular}{|c|c|c|}
\hline Diseases & Meningococcal disease & Yellow Fever \\
\hline Cause & $\begin{array}{l}\text { Neisseria meningitides serogroups } \mathrm{A}, \mathrm{B}, \mathrm{C}, \mathrm{Y} \text {, } \\
\mathrm{X}, \mathrm{W}-135 \text {. }\end{array}$ & Yellow fever virus and arbovirus of the Flavivirus genus. \\
\hline Transmission & $\begin{array}{l}\text { Transmission occurs by direct person-to-person } \\
\text { contact and through respiratory droplets from } \\
\text { patients or asymptomatic meningococcal } \\
\text { carriers. Humans are the only reservoir. }\end{array}$ & $\begin{array}{l}\text { Yellow fever occurs in urban and rural areas of Africa and } \\
\text { central South America. In jungle and forest areas, monkeys are } \\
\text { the main reservoir of infection, which is spread by mosquitoes } \\
\text { from monkey to monkey and occasionally, to humans. In } \\
\text { urban settings mosquitoes transmit the virus from human-to- } \\
\text { human. }\end{array}$ \\
\hline $\begin{array}{l}\text { General } \\
\text { precautions }\end{array}$ & $\begin{array}{l}\text { Avoid overcrowding in confined spaces. } \\
\text { Following close contact with an individual } \\
\text { suffering from meningococcal disease, medical } \\
\text { advice should be sought regarding possible } \\
\text { chemoprophylaxis and vaccination. }\end{array}$ & $\begin{array}{l}\text { Avoid mosquito bites (e.g. mosquito net and insecticide to treat } \\
\text { fabrics); the highest risk for YFV transmission is during the } \\
\text { day and early evening. }\end{array}$ \\
\hline Vaccines & $\begin{array}{l}\text { A, C, Y, W-135 vaccine. Saudi Arabia } \\
\text { demands proof of recent meningococcal } \\
\text { vaccination (tetravalent vaccine) as a visa } \\
\text { requirement for pilgrims and guest workers. } \\
\text { Recommended in the "meningitis belt" of sub- } \\
\text { Saharan Africa, a zone stretching across the } \\
\text { continent from Senegal to Ethiopia. }\end{array}$ & $\begin{array}{l}\text { Type of vaccine: Live, attenuated Recommended for: All } \\
\text { travellers to countries and areas with risk of yellow fever } \\
\text { transmission and when required by countries. Special } \\
\text { precautions: Not recommended for infants aged } 6-8 \text { months, } \\
\text { except during epidemics when the risk of YF virus } \\
\text { transmission may be very high. }\end{array}$ \\
\hline
\end{tabular}


Pre-travel precautions should include booster doses of routine vaccines if the regular schedule has not been followed, or a full course of primary immunization for people who have never been vaccinated. Adequate vaccinations should also be ensured for inhabitants of endemic areas travelling to non-endemic locations in order to prevent introduction/reintroduction of diseases such as polio, yellow fever, measles and rubella. WHO information on vaccine preventable diseases can be found at: http://www.who.int/immunization/.

Other vaccines will be advised on the basis of a travel risk assessment for the individual traveller. In deciding which vaccines would be appropriate, the following factors are to be considered for each vaccine:

- Risk of exposure to the disease

- Age, health status, vaccination history

- Reactions to previous vaccine doses, allergies

- Risk of infecting others

- Cost.

Nowadays, only yellow fever vaccination is, in certain situations, required by the International Health Regulations. Yellow fever vaccination is carried out for two different reasons: (1) to protect the individual in areas where there is a risk of yellow fever infection; and (2) to protect vulnerable countries from importation of the yellow fever virus. Travellers should therefore be vaccinated if they visit a country where there is a risk of exposure to yellow fever. In some non-endemic countries the yellow fever vaccination is a prerequisite for entry, for those who have recently passed through yellow fever-endemic areas.

Vaccination against meningococcal disease (quadrivalent vaccine) is required by Saudi Arabia for pilgrims visiting Mecca and Medina for the Hajj or Umrah as well as for seasonal workers. Some poliofree countries may also require travellers from countries or areas reporting wild polio viruses to be immunized against polio in order to obtain an entry visa, e.g. Saudi Arabia [7]. Travellers should be provided with a written record of all vaccines administered (patient-retained record), preferably using the international vaccination certificate (which is required in the case of yellow fever vaccination). The certificate can be ordered from WHO (Tables 3-6).

\section{Medical examination after travel}

Travellers should be advised to have a medical examination upon their return, according to The International Society of Travel Medicine (http://www.istm.org) or the American Society of Tropical Medicine and Hygiene (http://www.astmh.org), if they:

- Return with a fever from a country where malaria is, or may be, present so that malaria can be disregarded as a cause of illness.

- suffer from a chronic disease, such as cardiovascular disease, diabetes mellitus, or chronic respiratory disease or have been taking anticoagulants;

- experience illness in the weeks following their return home, particularly if fever, persistent diarrhoea, vomiting, jaundice, urinary disorders, skin disease or genital infection occurs;

- they received treatment for malaria while travelling;

- may have been exposed to a serious infectious disease while travelling;

- Have spent more than 3 months in a developing country.

Travellers should provide medical personnel with information on recent travel, including destination, purpose and duration of visit. Frequent travellers should give details of all journeys that have taken place in the preceding weeks and months including pre-travel vaccinations received and malaria chemoprophylaxis taken [6].

\section{References}

1. WHO (2012) International travel and health. Available: http://www.who.int/entity/ith/en/. Accessed 26 December 2013.

2. Ministerio de Sanidad, Servicios Sociales e Igualdad, Available

http://www.msssi.gob.es/profesionales/saludPublica/sanidadE xterior/docs/viajes_internacionales_y_salud_2012.pdf

3. Global Influenza Surveillance Network (FluNet). Available: http://www.who.int/GlobalAtlas/. Accessed 26 December 2013.

4. Information of vaccines from the Global Advisory Committee on Vaccine Safety. Available: http://www.who.int/vaccine_safety/en/. Accessed 16 December 2013.

5. WHO (2010) vaccine position papers. Available: http://www.who.int/immunization/documents/positionpapers intro/en/index.html. Accessed 26 December 2013.

6. Ministerio de Sanidad, Servicios Sociales e Igualdad (2014) Available

http://www.msssi.gob.es/profesionales/saludPublica/sanidadE xterior/salud/centrosvacu.htm). Accessed 28 December, 2013. 
7. Global Polio Eradication Initiative (2014) Available at http://www.polioeradication.org/ Data and monitoring/ Poliothisweek.aspx/. Accessed 28 December, 2013

8. National Travel Health Network and Centre. Health information for Overseas Travel "Yellow Book" (2010). Available: http://www.nathnac.org/yellow_book/YBmainpage.htm. Accessed 28 December 2013.

9. WHO (2012) International vaccination certificate. Geneva: World Health Organization. Available: http://www.who.int/ith/en/. Accessed 28 December 2013.

\section{Corresponding author}

Corresponding autor

Gema Ruíz López del Prado

Servicio de Medicina Preventiva y Salud Pública, Hospital Clínico

Universitario de Valladolid, Avda. de Ramón y Cajal 3, CP: 47005

Valladolid, Spain

Phone: + 0034983420000 (Ext: 86 129)

Email: cordoba_sweet@hotmail.com

Conflict of interests: No conflict of interests is declared. 